\title{
The Effects of Lead on the Meristem of Wheat Seedlings
}

\author{
Galina A. Semenova1, Irina R. Fomina ${ }^{2,3 *}$, Evgeniia A. Bakaeva ${ }^{4}$, Tamara I. Balakhnina ${ }^{2}$ \\ ${ }^{1}$ Institute of Theoretical and Experimental Biophysics, Russian Academy of Sciences, Moscow, Russia \\ ${ }^{2}$ Institute of Basic Biological Problems, Russian Academy of Sciences, Moscow, Russia \\ ${ }^{3}$ Biosphere Systems International Foundation, Tucson, AZ, USA \\ ${ }^{4}$ The Department of Morphology, P.G. Demidov Yaroslavl State University, Yaroslavl, Russia \\ Email:^irafomi@rambler.ru
}

How to cite this paper: Semenova, G.A., Fomina, I.R., Bakaeva, E.A. and Balakhnina, T.I. (2019) The Effects of Lead on the Meristem of Wheat Seedlings. CellBio, 8, 41-51. https://doi.org/10.4236/cellbio.2019.83003

Received: August 23, 2019

Accepted: September 27, 2019

Published: September 30, 2019

Copyright (C 2019 by author(s) and Scientific Research Publishing Inc. This work is licensed under the Creative Commons Attribution International License (CC BY 4.0).

http://creativecommons.org/licenses/by/4.0/ (c) (i) Open Access

\begin{abstract}
The ultrastructure of apical meristem cells was studied in Triticum aestivum L. cv. "Trizo" seedlings grown on soil without or enriched with selenium and survived 14 days' stress caused by lead pollution in the soil. The soil treatments: control-the original soil; (Pb1) - $50 \mathrm{mg} \cdot \mathrm{kg}^{-1} ;(\mathrm{Pb} 2)-100 \mathrm{mg} \cdot \mathrm{kg}^{-1}$; $(\mathrm{Pb} 1+\mathrm{Se} 1)-0.4 \mathrm{mg} \cdot \mathrm{kg}^{-1}$ Se added to $\mathrm{Pb} 1$ treated soil; $(\mathrm{Pb} 1+\mathrm{Se} 2)-0.8$ $\mathrm{mg} \cdot \mathrm{kg}^{-1} \mathrm{Se}$ added to $\mathrm{Pb} 1$ treated soil; $(\mathrm{Pb} 2+\mathrm{Se} 1)-0.4 \mathrm{mg} \cdot \mathrm{kg}^{-1}$ Se added to $\mathrm{Pb} 2$ treated soil; $(\mathrm{Pb} 2+\mathrm{Se} 2)-0.8 \mathrm{mg} \cdot \mathrm{kg}^{-1}$ Se added to $\mathrm{Pb} 2$ treated soil were used. Light and other conditions were optimal for plant growth. A distinctive feature of the cells of the apical meristem of control plants was the absence of nuclear membranes. Proplastids were membrane vesicles $1-2$ microns in diameter, filled with contents of varying degrees of density, from membrane vesicles containing only plastid DNA up to a fully formed structure of proplastids. In (Pb1)-plants, the amount of cytoplasmic ribosomes and proplastids in the meristematic cells was less than in the control. The structure of the forming proplastids was almost the same as that of the control plants. Signs of degradation of meristematic proplastids, such as a decrease of their diameter, observed in ( $\mathrm{Pb} 2)$-plants. The introduction of selenium into lead contaminated soil increased the accumulation of $\mathrm{Pb}$ in plants, especially in the roots and apical meristem. In (Pb1 + Se1)-, (Pb1 + Se2)-, (Pb2 + Se1)-, and (Pb2 + Se2)-plants, the number of cytoplasmic ribosomes in meristematic cells increased, which indirectly indicates an increase in protein synthesis. Based on our concept about the formation (assembly) of proplastids in the cells of the apical meristem, we believe that toxic agents, such as lead, which inhibit the development of proplastids into chloroplasts in mesophyll cells, act on apical meristem cells at the stage when plastid DNA is replicated in the cytoplasm
\end{abstract}


and is not yet surrounded by a plastid membrane.

\section{Keywords}

Apical Meristem, Lead, Selenium, Triticum aestivum

\section{Introduction}

Soil lead contamination caused, depending on the pollutant concentration, inhibition of plant growth, a decrease in the concentration of chlorophyll and photosynthesis, the excessive accumulation of $\mathrm{H}_{2} \mathrm{O}_{2}$ and thiobarbituric acid-reactive substances, and a change in the activity of antioxidant enzymes [1] [2].

The introduction of selenium into the soil had a multidirectional effect at different concentrations of the agent [1] [2]. Enrichment of soil with less dose of Se $\left(0.4 \mathrm{mg} \cdot \mathrm{kg}^{-1}\right)$ without $\mathrm{Pb}$ resulted in: stimulating growth processes; increasing ascorbate peroxidase activity in leaves and the activities of ascorbate peroxidase, guaiacol peroxidase, and glutathione reductase in plant roots; and reducing the amount of thiobarbituric acid-reactive substances. The introduction of the same dose of selenium into soil contaminated with $\mathrm{Pb}$ reduced the negative impact of lead on plants. The protective role of Se is considered to be related to decrease of heavy metal uptake and toxicity [3] [4].

Introduction of a larger $\left(0.8 \mathrm{mg} \cdot \mathrm{kg}^{-1}\right)$ dose of selenium into lead-free soil caused the suppression of growth processes and an increase in the thiobarbituric acid-reactive substances content during the activation of antioxidant enzymes in the roots and leaves [1]. The introduction of this dose of selenium into soil contaminated with $\mathrm{Pb}$ enhanced its negative effect, especially in the variant with a high concentration of lead [2].

As was also shown in the previous article [2], in wheat seedlings growing for 2 weeks in the light in pots with lead contaminated soil, the tissue of leaf blades became almost white. In the mesophyll cells of the whitened leaves, chloroplasts were absent, but there were etioplasts, which in this case were actually proplastids that did not develop into chloroplasts. In other words, despite the growth of the leaf plate, the formation of chloroplasts from proplastids was disrupted. All other cellular structures of leaf mesophyll cells did not differ from those in control plants that were not affected by the action of the stressor. The selectivity of the suppression of the chlorophyll synthesis process and, accordingly, the impossibility of the development of proplastids to chloroplasts indicated a point (target) effect of lead on this process. We assumed that the targets of the action of lead on the development of proplastids to chloroplasts are meristematic cells.

It is known that in the cells of the intercalary meristem, proplastids are well developed and are $1-2 \mu \mathrm{m}$ bodies, covered with a double membrane and containing a dense matrix. The cells of the growth cone meristem (apical meristem), in contrast to the intercalary meristem, are characterized by heterogeneity of the 
proplastid structure [5]. The structure of the proplastids of the apical meristem varies from transparent membrane vesicles containing plastid DNA to fully formed proplastids with a dense matrix (see [5]; and Figures 1-4). Such variability in the structure of proplastids suggests that in the apical meristem there is a process of formation (assembly) of the proplastid bodies [5], and not their simple division, as is commonly believed [6].

To clarify the effects of lead on the formation and development of proplastids in the apical meristem and the possibility of reducing the negative effects of lead at low concentrations of selenium, the aim of this work was to study the ultrastructural organization of the cells of the apical meristem of wheat seedlings survived 14 days' stress caused by lead pollution in soil (50 and $100 \mathrm{mg} \cdot \mathrm{kg}^{-1}$ ) without or with soil enrichment with selenium ( 0.4 and $\left.0.8 \mathrm{mg} \cdot \mathrm{kg}^{-1}\right)$. A 14-day growth period was selected based on previous studies [2] that showed that the leaves of the $\mathrm{Pb}$-treated plants were green during the first week of growth; after another week, etiolation occurred in the middle and bottom parts of these leaves.

\section{Materials and Methods}

Studies were carried out in 2017-2019 on the basis of three organizations: Institute of Basic Biological Problems, Russian Academy of Sciences (growing plants), Institute of Theoretical and Experimental Biophysics, Russian Academy of Sciences (electron microscopy), and P.G. Demidov Yaroslavl State University, the Department of Morphology (lead content measurements).

\subsection{Plant Growth Conditions}

The seeds of Triticum aestivum L. cv. "Trizo" (species Lutescens) after sterilization by $3 \% \mathrm{H}_{2} \mathrm{O}_{2}$ for 10 minutes were soaked in distilled water for 24 hours and germinated on moist filter paper in the dark for 2 days. Equally well-germinated seeds were sown in plastic pots (18 seeds per pot). The pots were filled with slightly acidic soil with low available nitrogen; medium contents of phosphorus and selenium, and the higher content of potassium (see [1]). The lead content in the soil did not exceed $6.27 \mathrm{mg} \cdot \mathrm{kg}^{-1}$. Plants were grown in under $300 \mu \mathrm{E} \cdot \mathrm{m}^{-2} \cdot \mathrm{s}^{-1}$ illumination at $16 / 8 \mathrm{~h}$ day/night photoperiod and $22 / 20^{\circ} \mathrm{C}$ day/night air temperature and investigated after 14-days growth.

\subsection{Soil Treatments}

Seven variants of the soil treatments in 3 replicates were prepared for plant cultivation: control-the original soil; (Pb1) - $50 \mathrm{mg} \cdot \mathrm{kg}^{-1} ;(\mathrm{Pb} 2)-100 \mathrm{mg} \cdot \mathrm{kg}^{-1}$; (Pb1 $+\mathrm{Se} 1)-0.4 \mathrm{mg} \cdot \mathrm{kg}^{-1}$ Se added to Pb1 treated soil; $(\mathrm{Pb} 1+\mathrm{Se} 2)-0.8 \mathrm{mg} \cdot \mathrm{kg}^{-1} \mathrm{Se}$ added to $\mathrm{Pb} 1$ treated soil; $(\mathrm{Pb} 2+\mathrm{Se} 1)-0.4 \mathrm{mg} \cdot \mathrm{kg}^{-1} \mathrm{Se}$ added to $\mathrm{Pb} 2$ treated soil; $(\mathrm{Pb} 2+\mathrm{Se} 2)-0.8 \mathrm{mg} \cdot \mathrm{kg}^{-1} \mathrm{Se}$ added to $\mathrm{Pb} 2$ treated soil. For this, $80 \mathrm{mg}(\mathrm{Pb} 1)$ or $160 \mathrm{mg}(\mathrm{Pb} 2)$ of $\mathrm{Pb}\left(\mathrm{NO}_{3}\right)_{2}$ were added per kg of dry soil as sours of lead. Selenium was applied in the form of $\mathrm{Na}_{2} \mathrm{SeO}_{4}$ at the concentration of $0.96 \mathrm{mg} \cdot \mathrm{kg}^{-1}$ (Se1) or $1.92 \mathrm{mg} \cdot \mathrm{kg}^{-1}$ (Se2), respectively. Weighted lead and selenium salts, cal- 
culated per $15 \mathrm{~kg}$ of air-dried soil, were dissolved in 1 liter of distilled water. Soil (15 kg for each variant) was placed on the plastic film, aligned and sprayed by hand sprayer with a thin layer of salt solution or water (control). After thorough mixing, the soil was brought up to full field water capacity and used to fill in 1-liter pots.

\subsection{Lead Content Measurements}

The decomposition of samples of dry plant material (leaves, roots, apical meristem) was carried out by wet ashing with a mixture of nitric acid and potassium nitrate on an electric stove, and then in a muffle furnace with an increase in temperature from $250^{\circ} \mathrm{C}$ to $450^{\circ} \mathrm{C}$. The microelement analysis of the samples was carried out by the method of inverse voltammetry on an AKB-07 MK instrument (Akvilon).

\subsection{Electron Microscopy Analyses of Meristematic Cells}

Pieces of shoots adjacent to the caryopsis 2 to $3 \mathrm{~mm}$ in height were fixed in a $2 \%$ glutaraldehyde solution on phosphate buffer ( $\mathrm{pH}$ 7.4) for $2 \mathrm{~h}$ followed by the postfixation in a $1 \% \mathrm{OsO} 4$ (Reakhim, Russia) solution. After dehydration in alcohols of increasing concentrations $50 \%-100 \%$ and $100 \%$ acetone, samples were embedded in Epon-812 (Fluka, Germany). Ultrathin sections were contrasted with a saturated aqueous uranyl acetate (Sewa, Czech Republic) solution and $0.25 \%$ lead citrate (British Drug Houses, England) by the conventional methods and examined in a JEM-100B electron microscope (Jeol, Japan) under an accelerating voltage of $80 \mathrm{kV}$. Quantitative measurements of organelles and inclusions were performed on ultrathin sections of meristem cells in the equatorial and sub-equatorial regions; the obtained data are estimates and not intended for statistical accuracy.

\section{Results}

\subsection{Lead Content in Leaves, Roots and Apical Meristem}

The lead concentration in the leaves of plants was relatively low in all treatments (Table 1). The concentration of lead in the roots and apical meristem was much higher than in the leaves. The introduction of selenium into soil contaminated with lead led to an increase in the absorption of $\mathrm{Pb}$ by plants, compared with the variants without selenium, especially to the roots and apical meristem. Characteristically, a lower dose of selenium (Se1) led to greater stimulation of lead uptake by plants, compared with a higher dose of selenium (Se2).

\subsection{Ultrastructure of Meristematic Cells}

Figure 1 and Figure 2 show the apical meristem of the control plants. A distinctive feature of this meristem is the absence of nuclear membranes (Figure 1). Proplastids are membrane vesicles $1-2$ microns in diameter, filled with contents of varying degrees of density, up to a fully formed structure of proplastids. Such 
structural heterogeneity from membrane vesicles containing only plastid DNA (Figure 2(a)) to fully formed proplastids (Figure 2(b)) is interpreted by us as stages of formation (assembly) of the proplastid bodies [5].

Table 1. $\mathrm{Pb}$ concentration in the leaves, roots and apical meristem of Triticum aestivum L. cv. Trizo seedlings grown on soil without or enriched with selenium $0.4 \mathrm{mg} \cdot \mathrm{kg}^{-1}$ (Se1) and $0.8 \mathrm{mg} \cdot \mathrm{kg}^{-1}(\mathrm{Se} 2)$, and survived 14 days' stress caused by lead $50 \mathrm{mg} \cdot \mathrm{kg}^{-1}(\mathrm{~Pb} 1)$ and $100 \mathrm{mg} \cdot \mathrm{kg}^{-1}(\mathrm{~Pb} 2)$.

\begin{tabular}{cccc}
\hline \multirow{2}{*}{ Soil treatment } & Leaves & Roots & Apical meristem \\
\cline { 2 - 4 } & \multicolumn{3}{c}{ Pb concentration, $\mu \mathrm{g} \cdot \mathrm{g}^{-1}$ dry weight } \\
\hline Control & $18.6 \pm 1.9$ & $102 \pm 11$ & $147 \pm 8$ \\
$\mathrm{~Pb} 1$ & $21.6 \pm 2.0$ & $158 \pm 13$ & $164 \pm 6$ \\
$\mathrm{~Pb} 1+\mathrm{Se} 1$ & $56.5 \pm 6.1$ & $971 \pm 95$ & $761 \pm 83$ \\
$\mathrm{~Pb} 1+\mathrm{Se} 2$ & $39.6 \pm 4.2$ & $869 \pm 90$ & $239 \pm 25$ \\
$\mathrm{~Pb} 2$ & $24.6 \pm 2.6$ & $455 \pm 50$ & $227 \pm 25$ \\
$\mathrm{~Pb} 2+\mathrm{Se} 1$ & $56.0 \pm 15$ & $632 \pm 71$ & $514 \pm 66$ \\
$\mathrm{~Pb} 2+\mathrm{Se} 2$ & $16.0 \pm 1.8$ & $389 \pm 42$ & $411 \pm 51$ \\
\hline
\end{tabular}

Values are expressed as means \pm S.D.

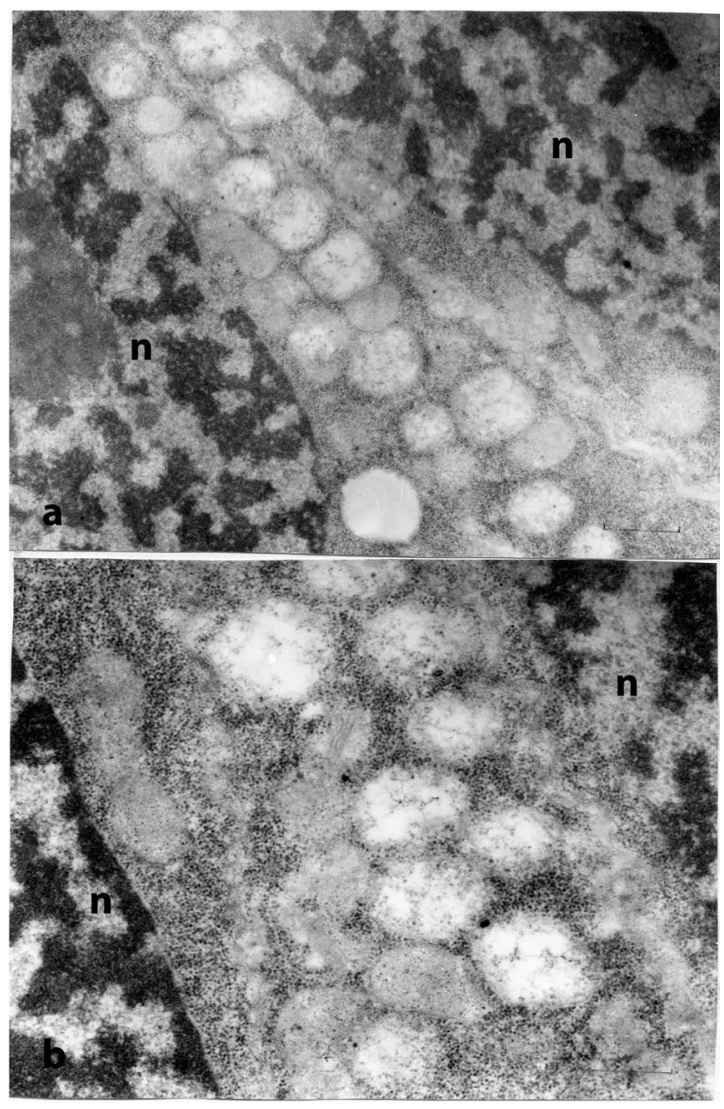

Figure 1. Cross sections of the apical meristem cells of Triticum aestivum L. cv. Trizo seedlings grown under control conditions. Proplastids tightly fill the cell space and have varying degrees of internal structuring. N, nucleus, scale bar $=1 \mu \mathrm{m}$. 


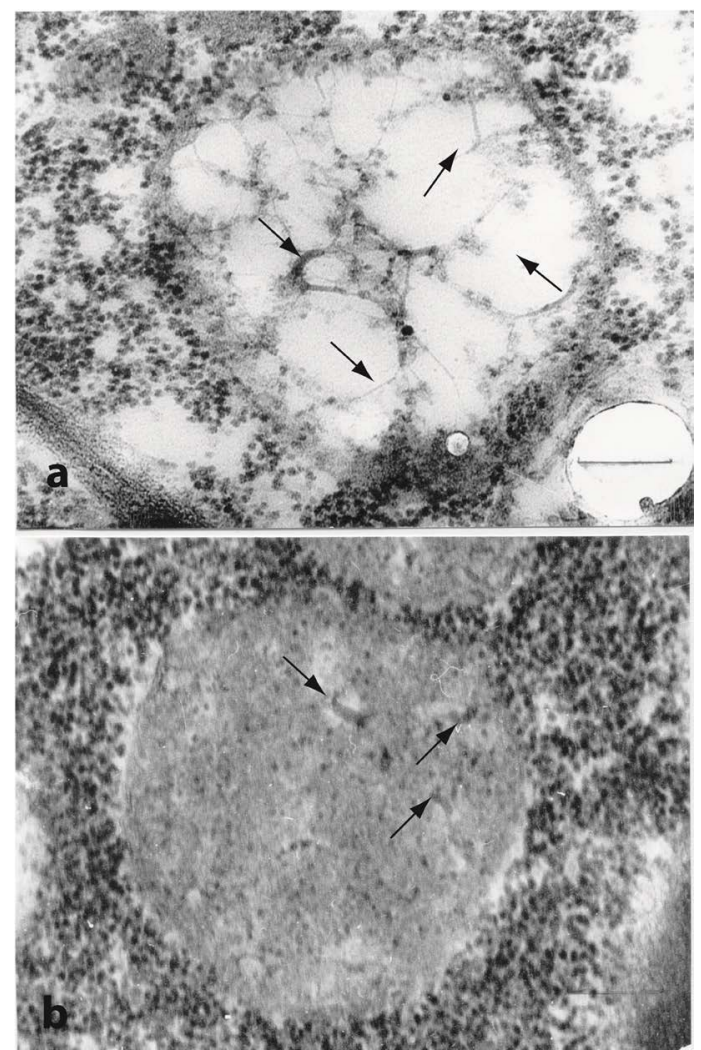

Figure 2. Proplastids of the apical meristem cells of Triticum aestivum L. cv. Trizo seedlings of the control plant at high magnification. (a) Juvenile proplastid, proplastid matrix is not yet formed. (b) Formed proplastid with a dense matrix and plastid ribosomes. Arrows indicate plastid DNA. Scale bar $=0.2 \mu \mathrm{m}$.

Figure 2(a) shows one of the stages of the formation of the proplastid body at high magnification. The body of the proplastid is filled mainly with 20 angstroms of plastid DNA. Separate parts of plastid DNA are in close contact with each other, forming aggregates of 2 - 10 strands (arrows in the photomicrograph). The proplastid membrane envelope is only partially formed on one side, and on the opposite side, direct contact between the cytoplasmic ribosomes and the plastid DNA strands can be seen. Such proplastids we will call juvenile.

Figure 2(b) shows a fully formed proplastid having a dense matrix containing plastid ribosomes in which plastid DNA (arrows in the photomicrograph) is immersed.

Figure 3 shows plots of the apical meristem of the experimental (Pb1)-plants and $(\mathrm{Pb} 1+\mathrm{Se} 1)$-plants. In (Pb1)-plants grown with lead content in the soil of 50 $\mathrm{mg} \cdot \mathrm{kg}^{-1}$, the amount of cytoplasmic ribosomes and proplastids in the meristematic cells is less than in the control (Table 2). However, the structure of the forming proplastids (Figure 3(a)) is almost the same as that of the control plants. Only a lower matrix density can be noted in fully formed proplastids of (Pb1)-plants as compared to the control.

With the additional introduction of $0.4 \mathrm{mg} \cdot \mathrm{kg}^{-1}$ selenium into the soil, $(\mathrm{Pb} 1+$ Se1)-treatment, the simultaneous presence in the same cell of both juvenile 
proplastids containing only plastid DNA and fully formed proplastids with membrane thylakoids is observed, and the cytoplasmic ribosomes are more numerous than in meristem cells of control plants (Figure $3(\mathrm{~b})$, Table 2). The ultrastructure of meristematic cells of $(\mathrm{Pb} 1+\mathrm{Se} 2)$-plants was the same as that of $(\mathrm{Pb} 1+\mathrm{Se} 1)$-plants (data not shown).

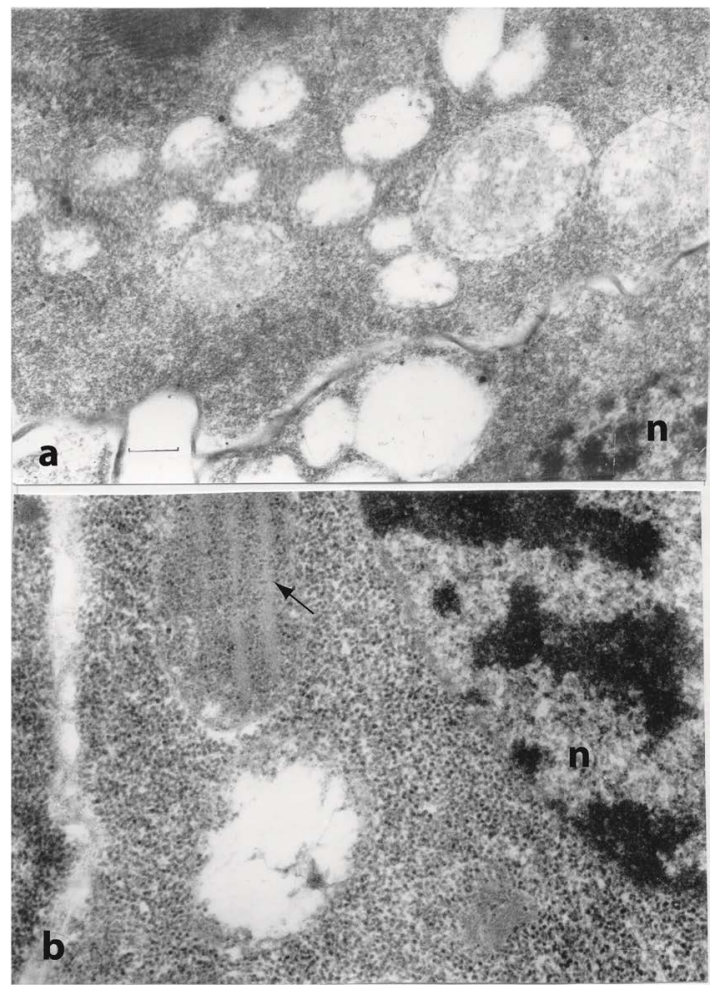

Figure 3. Cross sections of the apical meristem cells of Triticum aestivum L. cv. Trizo seedlings grown in soil: (a) with $50 \mathrm{mg} \cdot \mathrm{kg}^{-1} \mathrm{~Pb}\left(\mathrm{~Pb} 1\right.$ ), (b) with $50 \mathrm{mg} \cdot \mathrm{kg}^{-1} \mathrm{~Pb}$ and 0.4 $\mathrm{mg} \cdot \mathrm{kg}^{-1} \mathrm{Se}(\mathrm{Pb} 1+\mathrm{Se} 1)$. Arrow indicates forming thylakoids. N, nucleus, scale bar $=0.2 \mu \mathrm{m}$.

Table 2. Biometric parameters of the meristematic cells of the apical meristem of Triticum aestivum L. cv. Trizo seedlings grown on soil without or enriched with selenium 0.4 $\mathrm{mg} \cdot \mathrm{kg}^{-1}(\mathrm{Se} 1)$ and $0.8 \mathrm{mg} \cdot \mathrm{kg}^{-1}(\mathrm{Se} 2)$, and survived 14 days' stress caused by lead 50 $\mathrm{mg} \cdot \mathrm{kg}^{-1}(\mathrm{~Pb} 1)$ and $100 \mathrm{mg} \cdot \mathrm{kg}^{-1}(\mathrm{~Pb} 2)$.

\begin{tabular}{cccc}
\hline Soil treatment & $\begin{array}{c}\text { The density of ribosomes in the } \\
\text { cytoplasm, number per } \mu \mathrm{m}^{2} \text { of cell } \\
\text { cross section }\end{array}$ & $\begin{array}{c}\text { Diameter of } \\
\text { proplastid, } \mu \mathrm{m}\end{array}$ & $\begin{array}{c}\text { The number of } \\
\text { proplastids per cell slice }\end{array}$ \\
\hline Control & $1008 \pm 70$ & $1.2 \pm 0.10$ & $35 \pm 2.50$ \\
$\mathrm{~Pb} 1$ & $864 \pm 64$ & $0.9 \pm 0.08$ & $17 \pm 1.50$ \\
$\mathrm{~Pb} 1+\mathrm{Se} 1$ & $1080 \pm 75$ & $0.8 \pm 0.06$ & $16 \pm 1.10$ \\
$\mathrm{~Pb} 1+\mathrm{Se} 2$ & $0.9 \pm 0.08$ & $14 \pm 1.10$ \\
$\mathrm{~Pb} 2$ & $720 \pm 56$ & $0.5 \pm 0.03$ & $10 \pm 0.80$ \\
$\mathrm{~Pb} 2+\mathrm{Se} 1$ & $1080 \pm 73$ & $0.5 \pm 0.04$ & $20 \pm 1.50$ \\
$\mathrm{~Pb} 2+\mathrm{Se} 2$ & $1044 \pm 71$ & $0.8 \pm 0.07$ & $17 \pm 1.20$ \\
\hline
\end{tabular}

Values are expressed as means \pm S.D.; the data are estimates and are not intended for statistical accuracy. 
In (Pb2)-plants grown with lead content in the soil of $100 \mathrm{mg} \cdot \mathrm{kg}^{-1}$, signs of degradation are observed in the cells of the apical meristem (Figure 4). Namely, the density of ribosomes in the cytoplasm decreases to their complete absence in some cells (Figure 4(a), Table 2). Unlike the nuclei of the meristematic cells of control plants that are not covered by the nuclear envelope, the nuclei of the meristematic cells in ( $\mathrm{Pb} 2)$-plants have a clearly visible envelope (Figure 4(a)). The number of proplastids visible in the cross section is reduced (Table 2), juvenile proplastids are absent, and the formed proplastids have a much smaller diameter $(0.5 \mu \mathrm{m})$ than in the control (Table 2), and their matrix is compacted (Figure $4(\mathrm{~b}))$.

With the additional introduction of $0.8 \mathrm{mg} \cdot \mathrm{kg}^{-1}$ selenium into the soil, $(\mathrm{Pb} 2+$ Se2)-treatment, the number of proplastids in the meristematic cells also decreases and signs of their degradation are detected. It should be noted that the number of cytoplasmic ribosomes, on the contrary, is increased and exceeds control plants (Figures 5(a)-(c), Table 2). The ultrastructure of meristematic cells of $(\mathrm{Pb} 2+\mathrm{Se} 1)$-plants was the same as that of $(\mathrm{Pb} 2+\mathrm{Se} 2)$-plants, but signs of degradation of proplastids were less pronounced (data not shown).

\section{Discussion}

In previous works of this series of experiments [1] [2], mesophyll chloroplasts of

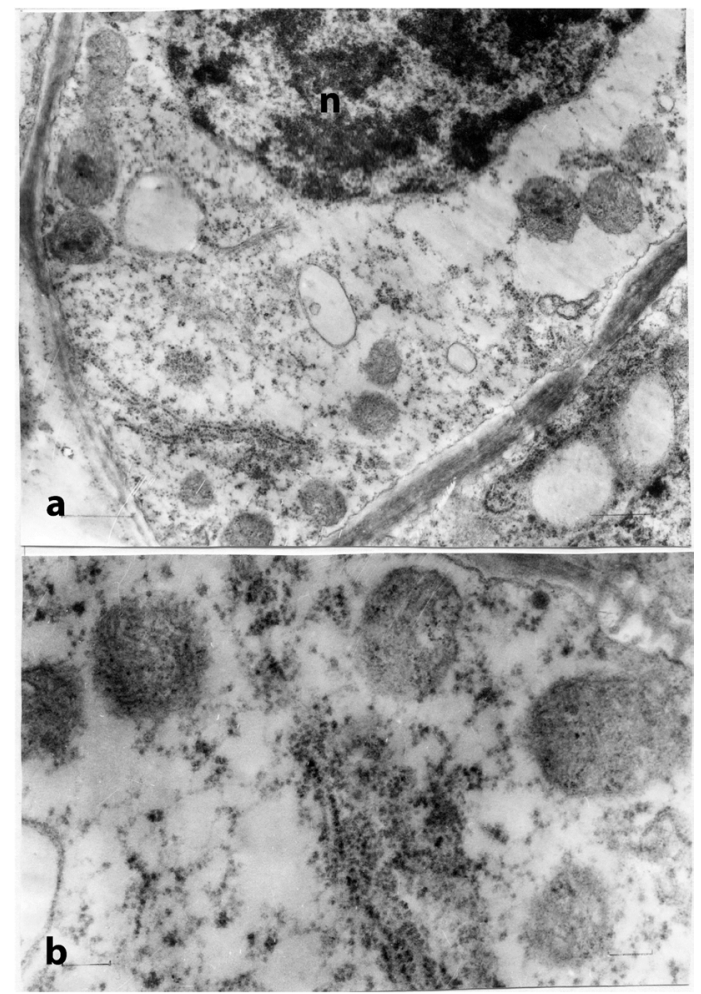

Figure 4. Cross sections of the apical meristem cells of Triticum aestivum L. cv. Trizo seedlings grown in soil with $100 \mathrm{mg} \cdot \mathrm{kg}^{-1} \mathrm{~Pb}(\mathrm{~Pb} 2)$. (a) The cytoplasm is not dense and contains only formed proplastids in a small number. (b) Formed proplastid at high magnification. $\mathrm{N}$, nucleus, scale bar $=1 \mu \mathrm{m}$ (a), scale bar $=0.2 \mu \mathrm{m}$ (b). 


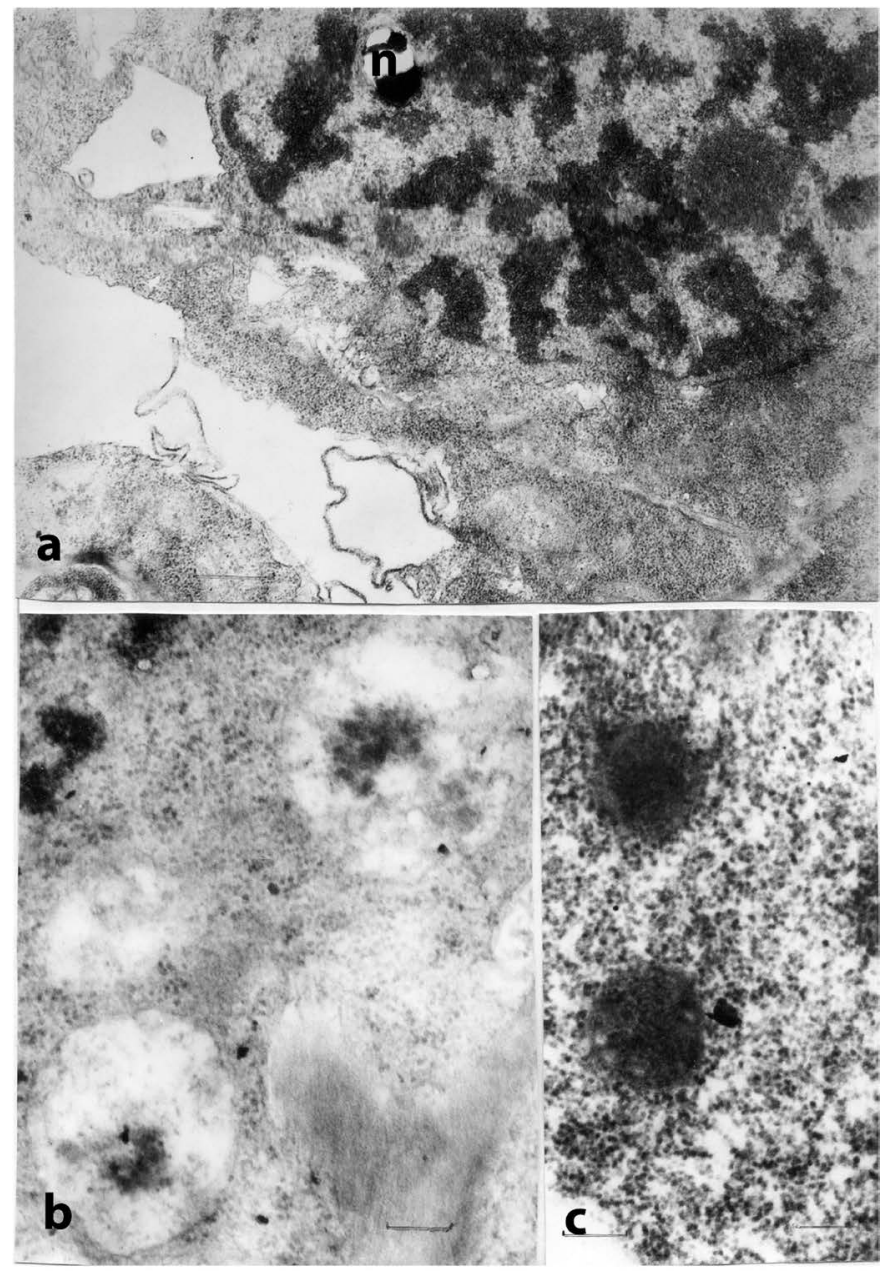

Figure 5. Cross sections of the apical meristem cells of Triticum aestivum L. cv. Trizo seedlings grown in soil with $100 \mathrm{mg} \cdot \mathrm{kg}^{-1} \mathrm{~Pb}$ and $0.8 \mathrm{mg} \cdot \mathrm{kg}^{-1} \mathrm{Se}(\mathrm{Pb} 2+\mathrm{Se} 2)$. (a) The cytoplasm contains many ribosomes and formed proplastids. (b) Formed proplastids with signs of degradation. (c) Proplastids at the final stage of degradation. N, nucleus, scale bar $=1 \mu \mathrm{m}(\mathrm{a})$, scale bar $=0.2 \mu \mathrm{m}((\mathrm{b}),(\mathrm{c}))$.

stressed plants showed signs of degradation. In most mesophyll cells chloroplasts were completely absent, the plastids were represented proplastids which did not develop into chloroplasts. Therefore, we assumed that $\mathrm{Pb}$ is likely to target meristem. Antagonistic effect of low concentration of $\mathrm{Se}$ and $\mathrm{Pb}$ in combination allowed to propose that Se generates some barriers for metal transfer from the wheat roots to the shoots as it was shown in mustard [3] and rice [4].

Surprisingly, it is the lover dose of selenium in the soil $\left(0.4 \mathrm{mg} \cdot \mathrm{kg}^{-1}\right)$, useful for wheat plants [2], that stimulates the intake of lead into plants, especially to the roots and apical meristem. We believe that selenium prevents the penetration of lead from the apoplast into the symplast.

On the other hand, the lower lead content in the leaves, roots and apical meristem of $(\mathrm{Pb} 2+\mathrm{Se} 2)$-plants compared with the $(\mathrm{Pb} 2+\mathrm{Se} 1)$-plants may be associated with the deep phase of development of extreme stress, suppression of the general level of metabolism. When inhibiting growth processes, the concentra- 
tion of plastid pigments, the intensity of photosynthesis, and also reducing not only the activity of antioxidant enzymes, but also the intensity of peroxide processes in $(\mathrm{Pb} 2+\mathrm{Se} 2)$-plants [1], the ability of plants to absorb nutrients from the soil, including the lead can be reduced.

Here we can note also that selenium when applied against a background of lead, compared with lead without selenium, probably caused stimulation of protein synthesis, as evidenced by a sharp increase in the number of ribosomes in the cytoplasm. However, protective inhibition of degradation, for example plastid DNA, was not detected.

Direct division of proplastids in the apical meristem of wheat was not observed. The increase in the number of proplastids required for cell division of the meristem seems to be carried out by a different mechanism (pathway) [5]. As shown in this work, in the cells of the apical meristem, the formation of juvenile proplastids is preceded by the stage of appearance of plastid DNA in the cytoplasm. Perhaps it is at this point that plastid DNA replicates. At this stage and somewhat later, when the proplastid membrane is not yet fully formed (see Figure 2(a)), toxic effects of various agents may occur. The decrease in the number of proplastids in the meristem of experimental plants subjected to stress is possibly due to the inhibition of plastid DNA replication when it is not yet protected by a plastid membrane.

\section{Conclusions}

Soil lead pollution of $50 \mathrm{mg} \cdot \mathrm{kg}^{-1}$ reduces the amount of proprastids in the cells of the apical meristem, but does not change their structure. Signs of degradation of proplastids occur at a higher lead dose of $100 \mathrm{mg} \cdot \mathrm{kg}^{-1}$. The introduction of selenium simultaneously with lead increases the number of cytoplasmic ribosomes in meristematic cells, which indirectly indicates an increase in protein synthesis.

Based on the concept [5] about the formation (assembly) of proplastids in the cells of the apical meristem, we believe that toxic agents, such as lead, which inhibit the development of proplastids into chloroplasts in mesophyll cells, act on apical meristem cells at the stage when plastid DNA is replicated in the cytoplasm and is not yet surrounded by a plastid membrane.

\section{Conflicts of Interest}

The authors declare no conflicts of interest regarding the publication of this paper.

\section{References}

[1] Balakhnina, T.I. and Nadezhkina, E.S. (2017) Effect of Selenium on Growth and Antioxidant Capacity of Triticum aestivum L. during Development of Lead-Induced Oxidative Stress. Russian Journal of Plant Physiology, 64, 215-223. https://doi.org/10.1134/S1021443717010022

[2] Semenova, G.A., Fomina, I.R., Kosobryukhov, A.A., Lyubimov, V.Yu., Nadezhkina, E.S. and Balakhnina, T.I. (2017) Mesophyll Cell Ultrastructure of Wheat Leaves Eti- 
olated by Lead and Selenium. Journal of Plant Physiology, 219, 37-44.

https://doi.org/10.1016/j.jplph.2017.09.008

[3] Fargašová, A., Pastierová, J. and Svetková, K. (2006) Effect of Se-Metal Pair Combinations $(\mathrm{Cd}, \mathrm{Zn}, \mathrm{Cu}, \mathrm{Pb})$ on Photosynthetic Pigments Production and Metal Accumulation in Sinapis alba L. Seedlings. Plant, Soil and Environment, 52, 8-15. https://doi.org/10.17221/3340-PSE

[4] Lin, L., Zhou, W., Dai, H., Cao, F., Zhang, G. and Wu, F. (2012) Selenium Reduces Cadmium Uptake and Mitigates Cadmium Toxicity in Rice. Journal of Hazardous Materials, 235-236, 343-351. https://doi.org/10.1016/j.jhazmat.2012.08.012

[5] Semenova, G.A. (2018) Formation of Proplastids in the Apical Meristem of Wheat. Journal of Plant Cell Development, 1, 23-30.

[6] Pyke, K.A. (2007) Plastid Biogenesis and Differentiation. In: Bock, R. (Ed.), Cell and Molecular Biology of Plastids, Topics Current Genetics, vol. 19, Springer, Berlin, Heidelberg, 1-28. https://doi.org/10.1007/4735_2007_0226 